\title{
A Study on Pattern of Identity Development among Adolescents
}

\author{
G. Swarupa Rani ${ }^{1}$, Dr. M. Sarada Devi ${ }^{2}$ \\ ${ }^{1} \mathrm{Ph} . \mathrm{D}$ scholar, Dept. of HDFS, C.H.Sc, Hyderabad \\ ${ }^{2}$ Professor \& Head of HDFS Department, C.H.Sc, Hyderabad
}

\begin{abstract}
The aim of this investigation was to study the pattern of identity development among adolescents of different categories. A sample number of 120 adolescents belonging to different age groups from schools and colleges were selected for the study. To know the identity development of adolescents a scale developed by Cheek and Briggs (2013) was used for data collection. The scale has 45 items divided into four sub headings such as personal, relational, social and collective identity development. Results of the study indicate that, almost equal percent of both boys (63\%) and girls (67\%) had average personal identity. Half of the girls sample (53\%) and only one fourth percent of the boy's sample (23\%) had high relational identity, which means compared to boys, girls had high relational identity. Social identity was high among more number of boys (85\%) than girls (62\%). With regard to collective identity, half of the boys sample and one fourth percent of the girls sample had high and average collective identity respectively. From the study it can be concluded that, both boys and girls are equally good at personal identity, more number of girls had high relational identity where as high percent of boys had high social identity and collective identity too.
\end{abstract}

Keywords: Identity, identity development and identity orientation

\section{Introduction}

Adolescence is a transitional period of growth and change including the development of mature forms of thought, emotion and behavior. Identity construction is a unique time in every adolescent's life. Noteworthy stage theorist, Erik Erikson, has illustrated the importance of identity formation in youth lives, further asserting that the age old question of 'who am I' adolescents are able to understand the importance of identity and that exploration is the primary means by which to achieve it. The later adolescents are able to use abstract thinking and place themselves into hypothetical situations to help them find the best fit' with regard to identities; they're great at using their imaginations to envision how others will see them upon the changes they enact. This is a transitioning period in life characterized by physiological, cognitive, biological, emotional, and hormonal changes. Lots of time and energy are invested on their part to reach this important goal as it goes the distance to fulfil their sense of belonging and accomplishment. Erikson impresses upon society that this is a highly mental and social process, rolling cues from the environment, opinions, observations, and reactions from friends and family into making the decision of which steps to take to find out who they are or in which direction to proceed (Schmitt et al., 2008).

Adolescents form their own personal sense of who they are based on many things, to include the reactions and opinions of family and friends as well as what is considered fun and chic by the parameters of the social contexts in which they live. Chief amongst all the input they use to form their identity is the feedback they get from family and friends. This feedback acts as a barometer to help them decide that personal identity mark (Schmitt et al., 2008).

The process of adolescence is a period of preparation for adulthood during this time several key developmental

experiences occur. The development of a strong and stable sense of self is widely considered to be one of the central tasks of adolescence. Identity refers to our sense of who we are as individuals and as members of social groups. According to Erikson (1968) the family helps in orienting children toward roles that are expected out of them at different stages of their lives. Furthermore, Rana and Shirali (2010) explained that family plays a critical role in adolescent identity formation by clarifying their confusion about change and transition.

Adolescents 'often search for uniqueness results in discontinuities in relationships with prior and existing organizations (Bronfenbrenner, 1993; Collins et al., 1997; Collins \& Russell, 1991, Fuligni, 1998; Grotevant \& Cooper, 1986; Lapsley, 1990; Noller, 1995). Under these circumstances the family context reportedly serves as a strong social system for adolescent identity formation (Marcia, 1993; Noller, 1995).

\section{Method}

\section{a) Selection of Sample}

- Purposive sampling procedure was used to select sample for the present study

- Sample comprised of 120 adolescents with equal number of boys and girls were selected for the study.

\section{b) Sampling Procedure}

Criteria for sample selection are:

1) Age range of adolescents should be between 13-21 years.

2) Students studying schools and colleges were selected for the study. 


\section{International Journal of Science and Research (IJSR) \\ ISSN (Online): 2319-7064}

Index Copernicus Value (2013): 6.14 | Impact Factor (2014): 5.611

Table 1: Details about distribution of sample

\begin{tabular}{|c|c|c|c|c|}
\hline S. No & Age & Boys & Girls & Total \\
\hline 1 & $13-15$ (early adolescents) & 20 & 20 & 40 \\
\hline 2 & $15-17$ years (Middle Adolescents) & 20 & 20 & 40 \\
\hline 3 & $17-21$ years (later adolescents) & 20 & 20 & 40 \\
\hline & Total & 60 & 60 & 120 \\
\hline
\end{tabular}

\section{c) Measurement Tools}

In order to find out the pattern of identity development of adolescents a questionnaire developed by Cheek and Briggs (2013) on aspects of identity development was used. The scale consists of 45 items and were divided into four subscales as

- Personal identity orientation: It is a sense of self within an individual that reflects more of an internal emphasis, based on self-knowledge and self-evaluation.

- Relational identity orientation: It is how we see ourselves in the context of our intimate relationships.

- Social identity orientation: It refers to one's popularity or social reputation deriving from interpersonal relationships.

- Collective identity orientation: Collective self, which reflects how we represent our various reference group identities.

\section{d) Procedure}

The adolescents belonging to three different categories (early, middle and later adolescents) were purposefully selected from schools and colleges of Hyderabad city. The collected data was coded and analyzed using frequencies and percentage to study the pattern of identity development adolescents of different categories.

\section{Results}

The identity development of adolescents was described in below tables

Table 2: Distribution of identity development of selected adolescents

I. Total Sample

\begin{tabular}{|c|c|c|c|c|c|c|c|c|}
\hline \multirow{2}{*}{$\begin{array}{l}S . \\
\text { No }\end{array}$} & \multirow{2}{*}{$\begin{array}{c}\text { Categories of } \\
\text { adolescents }\end{array}$} & \multirow{2}{*}{$\begin{array}{c}\text { Score } \\
\text { category }\end{array}$} & \multicolumn{2}{|c|}{ Boys $=20$} & \multicolumn{2}{|c|}{ Girls $=20$} & \multicolumn{2}{|c|}{ Total $=40$} \\
\hline & & & $F$ & $\%$ & $F$ & $\%$ & $F$ & $\%$ \\
\hline \multirow{3}{*}{1} & \multirow{3}{*}{$\begin{array}{l}\text { Personal } \\
\text { identity }\end{array}$} & Low & 0 & 0 & 1 & 2 & 1 & 1 \\
\hline & & Average & 38 & 63 & 40 & 67 & 78 & 65 \\
\hline & & High & 22 & 37 & 19 & 32 & 41 & 34 \\
\hline \multirow{3}{*}{2} & \multirow{3}{*}{$\begin{array}{l}\text { Relational } \\
\text { identity }\end{array}$} & Low & 0 & 0 & 0 & 0 & 0 & 0 \\
\hline & & Average & 46 & 77 & 28 & 47 & 74 & 62 \\
\hline & & High & 14 & 23 & 32 & 53 & 46 & 38 \\
\hline \multirow{3}{*}{3} & \multirow{3}{*}{$\begin{array}{c}\text { Social } \\
\text { identity }\end{array}$} & Low & 0 & 0 & 3 & 5 & 3 & 3 \\
\hline & & Average & 9 & 15 & 20 & 33 & 29 & 24 \\
\hline & & High & 51 & 85 & 37 & 62 & 88 & 73 \\
\hline \multirow{3}{*}{4} & \multirow{3}{*}{$\begin{array}{l}\text { Collective } \\
\text { identity }\end{array}$} & Low & 1 & 2 & 1 & 2 & 2 & 2 \\
\hline & & Average & 28 & 47 & 36 & 60 & 64 & 53 \\
\hline & & High & 31 & 52 & 23 & 38 & 54 & 45 \\
\hline
\end{tabular}

The above table gives the details of adolescents identity development, the selected sample comprises equal number of boys and girls. The adolescent's identity development will be measured in terms of four dimensions such as personal identity, relational identity, social identity and collective identity.
With regard to the dimension personal identity orientation which focuses on one's private conception of self and subjective feelings of continuity uniqueness, traits, values and abilities. It is clearly evident from the study that almost equal percent of both boys (63\%) and girls $(67 \%)$ had average personal identity orientation; where as $22 \%$ of boys and $32 \%$ of girls had high personal identity orientation. Though there was little difference between boys and girls scores, but on the whole girls had more scores on personal identity orientation than boys.

Regarding the dimension relational identity, this focuses on the importance that is placed on other people who are indirect personal contact. It was clearly noticed from the table that, three fourth percent of the adolescent boys (77\%) had average relational identity compared $47 \%$ of adolescent girls. Half of the girls sample $(53 \%)$ and only one fourth percent of the boys sample $(23 \%)$ had high relational identity, it was concluded from the table that average relational identity was more among boys but girls score was high on this particular dimension.

Social identity dimension describes adolescent's social roles and reputations and its importance in defining self, one's public image as presented through social roles and relationships. Results on social identity orientation dimension yielded very interesting fact i.e. majority of the boy's sample $(85 \%)$ had high social identity than girls of $62 \%$. Average social identity was more for girls than boys.

Collective identity represents the importance that is placed on social categories to which an individual belongs. From the results it is surprising to note that half of the boys sample compared to more than one fourth percent of the girls sample had high collective identity. Compared to boys $(47 \%)$ girls $(60 \%)$ had average score on this dimension.

Table 3: Personal identity orientation among adolescents of different categories

\begin{tabular}{|c|c|c|c|c|c|c|c|c|}
\hline \multirow{2}{*}{$\begin{array}{l}S . \\
N_{c}\end{array}$} & \multirow{2}{*}{\begin{tabular}{|l} 
Categories of \\
adolescents
\end{tabular}} & \multirow{2}{*}{$\begin{array}{c}\text { Score } \\
\text { category }\end{array}$} & \multicolumn{2}{|c|}{ Boys $=20$} & \multicolumn{2}{|c|}{ Girls $=20$} & \multicolumn{2}{|c|}{ Total $=40$} \\
\hline & & & $F$ & $\%$ & $F$ & $\%$ & $F$ & $\%$ \\
\hline \multirow[t]{3}{*}{1} & \multirow{3}{*}{$\begin{array}{c}\text { Early } \\
\text { adolescents }\end{array}$} & Low & 0 & 0 & 1 & 5 & 1 & 2 \\
\hline & & Average & 13 & 65 & 15 & 75 & 28 & 70 \\
\hline & & High & 7 & 35 & 4 & 20 & 11 & 28 \\
\hline \multirow[t]{3}{*}{2} & \multirow{3}{*}{$\begin{array}{c}\text { Middle } \\
\text { adolescents }\end{array}$} & Low & 0 & 0 & 0 & 0 & 0 & 0 \\
\hline & & Average & 8 & 40 & 14 & 70 & 22 & 45 \\
\hline & & High & 12 & 60 & 6 & 30 & 18 & 55 \\
\hline \multirow[t]{3}{*}{3} & \multirow{3}{*}{$\begin{array}{l}\text { Later } \\
\text { adolescents }\end{array}$} & Low & 0 & 0 & 0 & 0 & 0 & 0 \\
\hline & & Average & 9 & 45 & 11 & 55 & 20 & 50 \\
\hline & & High & 11 & 55 & 9 & 45 & 20 & 50 \\
\hline
\end{tabular}

The above table gives the details of sub dimensions of identity development, which includes the first dimension 'personal identity'. The early adolescents especially girls about $75 \%$ had average personal identity than boys of $65 \%$. Whereas $35 \%$ of boys than girls of $20 \%$ had high personal identity. There were not wide differences noticed between boys and girls who are belonged to early adolescent category.

It was interesting to notice from the results that middle adolescent boys about $2 / 3^{\text {rd }}$ percent and girls about $30 \%$ only had high scores. Girls about $70 \%$ had average score and it was very less among boys. It means more number of middle 


\section{International Journal of Science and Research (IJSR) \\ ISSN (Online): 2319-7064}

Index Copernicus Value (2013): 6.14 | Impact Factor (2014): 5.611

adolescent girls has average personal identity where as more number of boys had high scores on this particular dimension.

With regard to the later adolescent's personal identity, equal percent of both boys and girls had high and average identity development respectively. There were not much difference observed between boys and girls with regard to personal identity dimension.

On the whole it can be concluded from the above table that as age increases the scores on personal identity development were changed, during early and middle adolescent period $70 \%$ of the early adolescents and $55 \%$ of the middle adolescents had average personal identity whereas half of the later adolescents had higher level of personal identity.

Table 4: Relational identity orientation among adolescents of different categories

\begin{tabular}{|c|c|c|c|c|c|c|c|c|}
\hline \multirow{2}{*}{$\begin{array}{l}S . \\
\text { No }\end{array}$} & \multirow{2}{*}{$\begin{array}{c}\text { Categories of } \\
\text { adolescents }\end{array}$} & \multirow{2}{*}{$\begin{array}{c}\text { Score } \\
\text { category }\end{array}$} & \multicolumn{2}{|c|}{ Boys $=20$} & \multicolumn{2}{|c|}{ Girls $=20$} & \multicolumn{2}{|c|}{ Total $=40$} \\
\hline & & & $F$ & $\%$ & $F$ & $\%$ & $F$ & $\%$ \\
\hline \multirow{3}{*}{1} & \multirow{3}{*}{$\begin{array}{c}\text { Early } \\
\text { adolescents }\end{array}$} & Low & 0 & 0 & 0 & 0 & 0 & 0 \\
\hline & & Average & 15 & 75 & 9 & 45 & 25 & 62 \\
\hline & & High & 5 & 25 & 11 & 55 & 15 & 38 \\
\hline \multirow{3}{*}{2} & \multirow{3}{*}{$\begin{array}{c}\text { Middle } \\
\text { adolescents }\end{array}$} & Low & 0 & 0 & 0 & 0 & 0 & 0 \\
\hline & & Average & 16 & 80 & 10 & 50 & 26 & 65 \\
\hline & & High & 4 & 20 & 10 & 50 & 14 & 35 \\
\hline \multirow{3}{*}{3} & \multirow{3}{*}{$\begin{array}{c}\text { Later } \\
\text { adolescents }\end{array}$} & Low & 0 & 0 & 0 & 0 & 0 & 0 \\
\hline & & Average & 13 & 65 & 11 & 55 & 24 & 60 \\
\hline & & High & 7 & 35 & 9 & 45 & 16 & 40 \\
\hline
\end{tabular}

The above table gives the details of relational identity among adolescents belonging to three categories. Almost three fourth percent of boys from early and middle adolescent age group had average relational identity whereas only fifty percent of the girls from early and middle adolescents are having the average relational identity. It was interesting to notice from the table that early adolescent girls (55\%) compared to middle and later adolescent girls scored high on this dimension. Equal percent of girls from middle adolescent group had average and high scores respectively. Regarding the later adolescent's relational development, $35 \%$ of boys and $45 \%$ of girls had high scores. On the whole it can be concluded from the table that girls compared to boys had high relational identity it might be due to the reason that, girls in general maintains good communication skills than boys.

Table 5: Social identity orientation among adolescents of different categories

\begin{tabular}{|c|c|c|c|c|c|c|c|c|}
\hline \multirow{2}{*}{ S. No } & \multirow{2}{*}{\begin{tabular}{|c|} 
Categories of \\
adolescents
\end{tabular}} & \multirow{2}{*}{$\begin{array}{c}\text { Score } \\
\text { category }\end{array}$} & \multicolumn{2}{|c|}{ Boys $=20$} & \multicolumn{2}{|c|}{ Girls $=20$} & \multicolumn{2}{|c|}{ Total $=40$} \\
\hline & & & $F$ & $\%$ & $F$ & $\%$ & $F$ & $\%$ \\
\hline \multirow{3}{*}{1} & \multirow{3}{*}{$\begin{array}{c}\text { Early } \\
\text { adolescents }\end{array}$} & Low & 0 & 0 & 2 & 10 & 2 & 4 \\
\hline & & Average & 3 & 15 & 6 & 30 & 9 & 23 \\
\hline & & High & 17 & 85 & 12 & 60 & 29 & 73 \\
\hline \multirow{3}{*}{2} & \multirow{3}{*}{$\begin{array}{c}\text { Middle } \\
\text { adolescents }\end{array}$} & Low & 0 & 0 & 1 & 5 & 1 & 2 \\
\hline & & Average & 7 & 35 & 9 & 45 & 16 & 40 \\
\hline & & High & 13 & 65 & 10 & 50 & 23 & 58 \\
\hline \multirow{3}{*}{3} & \multirow{3}{*}{$\begin{array}{c}\text { Later } \\
\text { adolescents }\end{array}$} & Low & 0 & 0 & 0 & 0 & 0 & 0 \\
\hline & & Average & 4 & 20 & 6 & 30 & 10 & 25 \\
\hline & & High & 16 & 80 & 14 & 70 & 30 & 75 \\
\hline
\end{tabular}

The above table explains the details of social identity development among adolescents of different age groups. The sample in the early adolescent period, major percent of boys (85\%) had high scores compared boys and girls from other two categories. There were not wide differences observed between boys and girls of middle adolescent age group. Further with fewer differences even the later adolescent boys $(80 \%)$ and girls $(70 \%)$ were also had high social identity development. From the table it can be concluded that more number of boys from all the categories had high scores whereas more number of girls from all the groups had average scores on social identity which means boys had high social identity than girls.

Table 6: Collective identity orientation among adolescents of different categories

\begin{tabular}{|c|c|c|c|c|c|c|c|c|}
\hline \multirow{2}{*}{ S.N } & \multirow{2}{*}{$\begin{array}{c}\text { Categories of } \\
\text { adolescents }\end{array}$} & \multirow{2}{*}{$\begin{array}{c}\text { Score } \\
\text { category }\end{array}$} & \multicolumn{2}{|c|}{ Boys $=20$} & \multicolumn{2}{|c|}{ Girls $=20$} & \multicolumn{2}{|c|}{ Total $=40$} \\
\hline & & & $F$ & $\%$ & $F$ & $\%$ & $F$ & $\%$ \\
\hline \multirow{3}{*}{1} & \multirow{3}{*}{$\begin{array}{c}\text { Early } \\
\text { adolescents }\end{array}$} & Low & 1 & 5 & 1 & 5 & 2 & 5 \\
\hline & & Average & 8 & 40 & 10 & 50 & 18 & 45 \\
\hline & & High & 11 & 55 & 9 & 45 & 20 & 50 \\
\hline \multirow{3}{*}{2} & \multirow{3}{*}{$\begin{array}{c}\text { Middle } \\
\text { adolescents }\end{array}$} & Low & 0 & 0 & 0 & 0 & 0 & 0 \\
\hline & & Average & 12 & 60 & 14 & 70 & 26 & 65 \\
\hline & & High & 8 & 40 & 6 & 30 & 14 & 35 \\
\hline \multirow{3}{*}{3} & \multirow{3}{*}{$\begin{array}{c}\text { Later } \\
\text { adolescents }\end{array}$} & Low & 0 & 0 & 0 & 0 & 0 & 0 \\
\hline & & Average & 11 & 55 & 12 & 60 & 23 & 58 \\
\hline & & High & 9 & 45 & 8 & 40 & 17 & 42 \\
\hline
\end{tabular}

The table reveals the results of collective identity among adolescents of three age groups. It was interesting to notice from the above table that, very less percent of early adolescent boys and girls had low score on collective identity. Half of the girls sample belonging to early adolescent category had average collective identity and $40 \%$ of the boys who are also belonging to same category had high scores on this particular dimension. Regarding middle age group adolescents $40 \%$ of boys and $70 \%$ of girls had high and average scores respectively. Coming to later adolescents, very fewer differences were noticed between boys and girl's score, boys compared to girls had high scores, whereas more number of girls had average scores on collective identity.

\section{Conclusion}

The findings of the investigation revealed that, almost equal percent of both boys $(63 \%)$ and girls $(67 \%)$ had average personal identity. Half of the girls sample $(53 \%)$ and only one fourth percent of the boy's sample $(23 \%)$ had high relational identity, which means compared to boys, girls had high relational identity. Social identity was high among more number of boys $(85 \%)$ than girls $(62 \%)$. With regard to collective identity, half of the boys sample and one fourth percent of the girls sample had high and average collective identity respectively. From the study it can be concluded that, both boys and girls are equally good at personal identity, more number of girls had high relational identity where as high percent of boys had high social identity and collective identity too. And further the results of the study also shows the differences between three categories of adolescents like later adolescents compared to early and 


\section{International Journal of Science and Research (IJSR) \\ ISSN (Online): 2319-7064}

Index Copernicus Value (2013): 6.14 | Impact Factor (2014): 5.611

middle age group adolescents had much better scores on almost all the dimensions of identity development.

\section{References}

[1] Cheek, J. M., and Briggs, S. R. 2013. Aspects of Identity Questionnaire (AIQ-IV).

[2] Measurement Instrument Database for the Social Science. www.midss.ie

[3] Collins, W.A., Laursen, B., Mortensen, N., Leubker, C., \& Ferreira, M. 1997 Conflict processes and transitions in parent and peer relationships: Implications for autonomy and regulation. Journal of Adolescent Research, 12, 178-198.

[4] Erikson, E. H. 1968. Identity, youth and crisis. New York: W. W. Norton Company, Behavioral Science. 14(2):154-159.

[5] Rana and Shirali,. 2010. Identity and family functioning link: An investigation of Indian youth. Journal of Psychology, 36.266-271

[6] Schmitt, D. P., Realo, A., Voracek, M., and Allik, J. 2008. Why can't a man be more like a woman? Sex differences in Big Five personality traits across 55 cultures. 94(1):168-82. 